Ph. Dr. Zeliha Tras ${ }^{1}$

Education Faculty, Necmettin Erbakan University, Konya, Turkey

Büșra Kabakci², Master Student

Education Faculty, Necmettin Erbakan University, Konya, Turkey

Umay Bilge Baltaci3, PhD Student

Education Faculty, Necmettin Erbakan University, Konya, Turkey
Original scientific paper

UDC: 371.15

DOI: $10.5937 /$ IstrPed2101251T

\title{
INVESTIGATION OF THE PSYCHOLOGICAL RESILIENCE OF TEACHER CANDIDATES IN TERMS OF SENSE OF HUMOR AND LIFE SATISFACTION
}

\begin{abstract}
The aim of this study is to examine the psychological resilience in teacher candidates in terms of sense of humor and life satisfaction. Correlational research model was used in the study. The dependent variable of the research is psychological resilience and independent variables are sense of humor and life satisfaction. The research was carried out on 427 teacher candidates between the ages of $18-27,318$ females (74.5\%) and 109 males (25.5\%). The Resilience Scale for Adults, The Multidimensional Sense of Humor Scale, The Satisfaction with Life Scale and Personal Information Form were used to collect data. Descriptive statistics, independent groups t-test, variance analysis, Pearson correlation coefficient and hierarchical regression analysis were used to analyze the data. When the findings of the study are analyzed, it is seen that psychological resilience in terms of gender differs significantly in favor of female teacher candidates. A positive relationship was found between teacher candidates' psychological resilience and sense of humor. In addition, a positive relationship was found between psychological resilience and life satisfaction. Looking at the findings, it is seen that the variables of sense of humor and life satisfaction predict psychological resilience significantly. The findings were discussed according to the literature and various suggestions were presented.
\end{abstract}

Key words: Resilience, sense of humor, life satisfaction, teacher candidates.

People struggle with something from the moment they are born. Throughout their lives, people typically encounter various difficulties, from daily troubles to large life events (Fletcher and Sarkar, 2013). A serious illness, abuse, loss of a relative, torture, and natural disaster can be given as examples to these various experiences (Dogru, 2019). It is important for individuals to cope with and adapt to ongoing negativities such as crises, traumas, and loss of attachment. The concept of resilience includes an individual's ability to adapt to acute or chronic stress factors throughout her/his life (Smith and Ascough, 2016). The concept of psychological resilience is one of the study subjects of positive psychology, which focuses on the development of people, positive emotions and relationships (Graber, Pichon and Carabine, 2015).

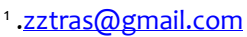

²busrakabakcii@hotmail.com

3 umaybilgee@gmail.com
} 
Various researches have been conducted on psychological resilience (Yavuz, 2019; Aydin, Oncu, Akbulut and Kucuk-Kilic, 2019; Tras, Oztemel and Kagnici, 2019; Celik, Sanberk and Deveci, 2017; Gungormis, Okanli and Kocabeyoglu, 2015; Koc-Yildirim, Yildirim, Otrar and Sirin, 2015; Malkoc and Yalcin, 2015; Sarikaya, 2015). It is seen that psychological resilience conceptis used with expressions such as indomitableness (Onat, 2010; Kaner, Bayrakli and Guzeller, 2011; Buyuksahin Cevik, Dogan and Yildiz, 2016; Ciftci-Arindag and Unsal-Seydoogullari, 2019), psychological strength (Karairmak and Sivis-Cetinkaya, 2011; Arslan and Balkis, 2016), and selfrecovery power (Isik, 2016; Cetinkaya and Sarici-Bulut, 2019) in the literature.

Psychological resilience can be generally defined as positive emotional and/or behavioral adaptation to negative situations (Choi, Stein, Dunn, Koenen and Smoller, 2019). According to Grotberg (1995), psychological resilience is a versatile and functional mechanism that we are endowed with, that is shaped within the scope of the opportunities offered and the environment we live in, and that offers us the opportunity to cope with problems in a crisis or in daily life. According to Henderson and Milstein (1996), psychological resilience is a mechanism that enables people to survive and sometimes become stronger after encountering a traumatic event. Psychological resilience is influenced by conscious awareness and spiritual well-being (Yavuz, 2019), leisure time assessment style and involvement in individual sports (Aydin et al., 2019), and involvement in art-based reflective activities (McKay and Barton, 2018). Ability to adapt to the social environment, and being able to provide emotional stabilization in their lives and social relationships positively affects the psychological resilience levels of individuals (Basim and Cetin, 2011). The increase in the psychological resilience levels of the parents positively affects the social competence level of their children and plays an important role in reducing anxiety and anger levels of the children (Kindiroglu and Yasar-Ekici, 2019). As the problem- solving skill increases, individuals provide more satisfaction from their social relationships and this affects psychological resilience process positively (Akdogan and Yalcin, 2018).

Another factor that is effective in increasing psychological resilience is having positive emotional experiences (Judd, 2016). One of the sources of positive emotional experiences is sense of humor concept associated with positive psychological structures (Papousek et al., 2019; Maiolino and Kuiper, 2014). Psychological functions of humor include the cognitive and social benefits of the positive emotion of mirth, and its uses as a form of social communication and influence, and as a way of relieving tension, regulating emotions and coping with stress (Martin, 2006). According to psychoanalytic theory, the place of humor in dealing with the tension and anxiety caused by the problem is an attempt to deal with anxiety and tension that a person experiences through jokes, caricatures or wit (Levine, 2017). People show their resilience when they respond to stressful situations with humor or laughter instead of fear or anger, and by doing this, they avoid unfruitful emotions (Hughes, 2008). There are benefits provided to the individual by the positive use of humor (Tras, Arslan and Mentis Tas, 2011). One of these benefits can be considered as increasing the psychological resilience of the individual by using humor. In other words, individuals who have the ability to use positive emotions such as developing effective relaxation techniques by using sense of humor can be considered to have high psychological resilience (Shin, Taylor and Seo, 2012). Increased psychological resilience plays a role in the relationship between positive emotional experiences and increased life satisfaction (Cohn, Fredrickson, Brown, Mikels and Conway, 2009). 
Life satisfaction, which is thought to increase psychological resilience, is one of the important concepts of positive psychology (Huang, Han, Sun, Zhang and Li, 2019; Proctor, Linley and Maltby, 2009). Life satisfaction is almost always a component of quality of individual life definitions and assessments, even when the individual's life quality includes objective living standards and functional abilities (Bailey, Eng, Frisch and Snyder, 2007). In general, evaluating many areas of life and what one has and what $s /$ he wants to have, comparing her/his dreams and desires are related to the concept of "life satisfaction" (Erdinc, 2018). The life satisfaction levels of people who are more successful in regulating and controlling their emotions in terms of experiences also differ significantly (Bakan and Guler, 2017). In studies supporting the argument that personality plays a role in determining life satisfaction, psychological resilience has been found to be associated with life satisfaction (Sousa and Lyubomirsky, 2001).

When the relevant literature is considered, it is understood that it is important to examine the concept of psychological resilience with different variables. Accordingly, the aim of this study is to examine the psychological resilience of teacher candidates according to their sense of humor and life satisfaction.

\section{Method}

\section{Research Model}

In this study, correlational research model was used to examine the relationship between psychological resilience, humor and life satisfaction. Correlational research model is used to determine the relationships between variables (Shaughnessy, Zechmeister and Zechmeister, 2012). The dependent variable of this research is psychological resilience and independent variables are humor and life satisfaction.

\section{Study group}

The study group of this research consists of 427 prospective teachers in total, 318 females (74.5\%) and 109 males (25.5\%), studying at a university in Central Anatolia. The ages of the participants vary between $18-27$ and the average age is 22 .

\section{Data Collection Tools}

The Resilience Scale for Adults: The adaptation of the scale (RSA) to Turkish, developed by Friborg, Hjemdal, Rosenvinge and Martinussen, (2003), was made by Basim and Cetin (2011). The scale has 33 items. The scale is a 5-point Likert type. As the scores increase, psychological resilience increases. Confirmatory factor analysis results of the scale were $\chi^{2}=1104, \mathrm{df}=480$, $\chi_{2} / \mathrm{df}=2,3, \mathrm{RMSEA}=0,055 ; \mathrm{TL}=0.90 ; \mathrm{CFI}=0.91$. Internal consistency coefficients ranged between .66 and .81 and test-retest reliability coefficients ranged between .68 and .81 (Basim and Cetin, 2011). The validity and reliability results of the scale seem to be appropriate. Cronbach Alpha value was found as .86 for this research.

The Satisfaction with Life Scale: The scale was developed by Diener, Emmons, Larsen and Griffin (1985). The original scale consists of 5 items in a 7-point Likert model. The scale was adapted to Turkish by Koker (1991). The scale, which was readapted by Baysal and Dagli (2016), has been changed as 5-point likert, considering that the 7-point likert type is not suitable for Turkish culture. Fit indices of the model are found as, $\chi_{2} / \mathrm{sd}=1.17, \mathrm{NFI}=0.99$; $\mathrm{NNFI}=1.00, \mathrm{CFI}=1.00 ; \mathrm{SRMR}=0.019 \mathrm{RMSEA}=0.030, \mathrm{GFI}=0.99, \mathrm{AGFI}=0.97$. It seems that the model fits well. Cronbach Alpha internal consistency coefficient of the scale was found as .88 . 
It is seen that the scale has acceptable reliability and validity coefficients (Baysal and Dagli, 2016). Cronbach Alpha value was found as .81 for this research.

The Multidimensional Sense of Humor Scale: The scale (MSHS) was developed by Thorson and Powell (1993).It was adapted to Turkish byAslan, Alparslan, Evlice, Aslan and Cenkseven, (1999), and an update work was carried out by Ozdogru (2018). The scale consists of 24 items. It is a 4-point Likert type. The scale, which consists of 4 sub-dimensions, is also evaluated over the total score. Varimax rotation was used for the validity of the scale, and it was determined that 4 factors explained $55 \%$ of the total variance (Ozdogru, 2018). As the score obtained from the scale increases, the general sense of humor increases. The Cronbach Alpha value of the total score of the scale was found as .89. Cronbach Alpha value was found as .89 for this study.

The data collection process was carried out in the 2020-2021 academic year. The application of the research was carried out by the students in the classrooms. The participants were informed about the purpose of the research and the scales. It was stated to the participants that only volunteers could participate in the research and stop filling out the scale form at any time. The application took approximately 30 minutes.

\section{Data Analysis}

SPSS 20.00 package program was used in the statistical analysis of the data. In the research, descriptive statistics were used to get general information about variables and research group; independent samples t-test to examine whether the level of psychological resilience differs according to gender variable; and Pearson Moments Product Correlation Coefficient and hierarchical regression analysis methods to examine the relationships between variables.

\section{RESULTS}

Table 1. Descriptive Findings Related to the Resilience Scale for Adults

\begin{tabular}{|lllll|}
\hline \multicolumn{9}{c|}{ Descriptive Findings } \\
& $\mathbf{X}$ & Sd & Skewness & Kurtosis \\
RSA & 123.98 & 16.84 & -.120 & -.153 \\
Humor & 64.76 & 13.60 & -.361 & -.043 \\
Life Satisfaction & 15.04 & 3.38 & 3.075 & -.001 \\
\hline
\end{tabular}

33 data that were found to be missing and outliers in the study were excluded from the study. Mahalanobis Distance, Cook's Distance Leverage values were used to extract the outlier. Mahalanobis Distance, Cook's Distance and Leverage values are used to determine the outlier (Kannan and Manoj, 2015). As it can be seen in Table 1, it can be accepted that the scales to be used in the research have normal distribution since the value of skewness and kurtosis is between \pm 1 . . If the skewness and kurtosis values of the variables are between \pm 1.0 , the distribution can be assumed to be normal (George and Mallery, 2019).

Table 2. Investigation of Psychological Resilience by Gender Variable

\begin{tabular}{|lllll|}
\hline Gendern & $X$ & Sdt & $p$ & $\eta 2$ \\
Females & 318 & 125.21 & 16.92 & $2,794.010 * .029$ \\
Males & 109 & 120.40 & 16.14 & \\
$\mathrm{p}<.05$ & & & & \\
\hline
\end{tabular}


When Table 2 is examined, the psychological resilience score averages of female teacher candidates $\left(\mathrm{X}^{-}=125.21\right)$ are significantly higher than that of male teacher candidates $\left(\mathrm{X}^{-}=\right.$ 120.40).

Table 3. Correlations of variables

\begin{tabular}{|lll|}
\hline Variables PR & SH & LS \\
1. Psychological Resilience & $-.287 * *$ & $.421 * *$ \\
2. Sense of humor & - & .068 \\
3. Life Satisfaction & - & \\
$* * p<.01$ & & \\
\hline
\end{tabular}

When Table 3 is examined, it is seen that there is a positive relationship between psychological resilience and sense of humor $(r=.28, p<.01)$ and life satisfaction $(r=.421, p$ $<.01)$.

Table 4. Hierarchical Regression Analysis Findings Regarding Prediction of Psychological Resilience

\begin{tabular}{|c|}
\hline Model Variables BSE ßtR ${ }^{2} \mathbf{R}^{2}$ change Tolerance VIF \\
1 Constant 96.1692 .99832 .082 .177 .177 \\
Life Satisfaction $1.849 .193 .4219 .576 * * * 1.0001 .000$ \\
2 Constant76.560 4.30317 .793 .244 .067 \\
Life Satisfaction $1.771 .186 .4049 .537 * * * .9951 .005$ \\
Humor.321.052.259 $6,128 * * * .9951 .005$ \\
Depen \\
Model-1: $\mathrm{R}=.421, \mathrm{R}^{2}=.177, \Delta \mathrm{R}^{2}=.176, \mathrm{~F}{ }_{(1-425)}=91.704, \mathrm{p}<.001$ \\
Model-2: $\mathrm{R}=.494 \mathrm{R}^{2}=.244, \Delta \mathrm{R}^{2}=.241, \mathrm{~F}(2-424)=68.568, \mathrm{p}<.001$ \\
Model 1. Predictors: Life Satisfaction \\
Model 2. Predictors: Life Satisfaction, Humor
\end{tabular}

To make the regression analysis, it is necessary to provide some postulations. If the tolerance value is greater than .20 and VIF is less than 5 , it is an indication that there is no multicollinearity problem (Gaur and Gaur, 2006). As seen in Table 4, Tolerance and VIF values are in the expected range. Another postulation is that Durbin Watson value is between 1.5 and 2.5 as an indication that there is no autocorrelation (Ho, 2016). In this study, the value of Durbin Watson is acceptable as it is found to be 2.111 .

As seen in Table 4, in the hierarchical regression analysis, the life satisfaction scale was entered into the analysis in the first block. In the second block, the Multidimensional Sense of Humor Scale was added. As a result of the analysis, the Satisfaction with Life Scale in the first block predicted the Resilience Scale for Adults significantly $\left(B=.42, R=.421, R^{2}=.177, \Delta R^{2}=\right.$ $\left..176, F_{(1-425)}=91.704, p<.001\right)$. Life Satisfaction explains about $18 \%$ of the total variance related to Psychological Resilience. In the second block, the Multidimensional Sense of Humor Scale was added. Independent variables in block 2 predicted Psychological Resilience significantly ( $R$ $\left.=.494 \mathrm{R}^{2}=.244, \Delta \mathrm{R}^{2}=.241, \mathrm{~F}_{(2-424)}=68.568, \mathrm{p}<.001\right)$. The strongest predictor variable is Life Satisfaction $(B=.40)$. Then comes Humor $(B=.25)$. Independent variables explain approximately $24 \%$ of the total variance related to Psychological Resilience.

\section{Discussion, Conclusion and Suggestions}

In this study, it was found that psychological resilience according to gender was found to differ significantly in favor of females. Some studies also support this finding (Yaprak, Guclu, Ayyildiz Durhan, 2018; Durmus and Okanli, 2018; Kilicand Alver, 2017; Koc-Yildirim, Yildirim, 
Otrar and Sirin; 2015; Gungormis, Okanli and Kocabeyoglu, 2015; Newsome, Vaske, Gehring and Boisvert, 2015; Bozgeyikli and Sat, 2014, Sheard, 2009;). While some studies reveal that psychological resilience shows a significant difference in favor of males (Tasgin, Bozgeyikli and Bogazliyan, 2017; Kaur, 2011), there are also research results showing that psychological resilience does not differ significantly by gender (Ak, 2019; Karmalkar and Vaidya, 2018; Aydin and Egemberdiyeva, 2018; Bektas and Ozben, 2016; Sabouripour and Roslan, 2015; Aydogdu, 2013; Ulker-Tumluand Recepoglu, 2013; Sezgin, 2012). There has not been a common conclusion about the effect of gender on psychological resilience in the literature. This may be due to the fact that gender differences need to be explained not only from the perspectives of maturation or biological development, but also from the cultural perspective (Limura andTaku, 2018).

When the relationship between psychological resilience and sense of humor was examined, a statistically significant positive relationship was found. In addition, humor is a significant predictor of psychological resilience. In the research conducted by Karlyk-Cwik (2016), supportive results have been reached which state that as the sense of humor increases, psychological resilience also increases. In some studies, significant positive relationships were found between humor styles and resilience (Bhattacharyya, Jena and Pradhan, 2019; Cann and Collette; 2014). Humor is suggested as a tool that can be used to strengthen psychological resilience (Wijewardena, Hartel, and Samaratunge, 2010). Resilience is not only managing and maintaining a negative process, but is also characterized with a positive response or development as a result of the event (Hughes, 2008). Therefore, it can be thought that individuals increase their psychological resilience by using humor. It can be thought that this effect of humor, which is one of the sources of positive emotional experiences, on psychological resilience arises from the positive relationship between psychological resilience and having positive emotional experiences (Papousek et al., 2019; Judd, 2016).

Another finding of the study is that there is a positive relationship between psychological resilience and life satisfaction. In addition, life satisfaction is a significant predictor of psychological resilience. Similarly, in a study conducted by Liu, Wang, and Lu (2013), a significant positive relationship was found between psychological resilience and life satisfaction of undergraduate students. In another study, a significant positive relationship was found between the life satisfaction and psychological resilience of older individuals (Zheng, Huangand Fu; 2020). In a study conducted on adolescents, a significant positive relationship was found between adolescents' life satisfaction and psychological resilience (Ramos-Diaz, Rodriguez-Fernandez, Axpeand Ferrara, 2019). There are also studies in which life satisfaction predicts psychological resilience (Yakici and Tras, 2018; Sahin-Baltaci and Karatas, 2015; Altundag and Bulut, 2014). When the literature is examined, it is seen that there are studies supporting the finding that life satisfaction increases as psychological resilience increases (Zhang, Yu, Zhang and Zhou, 2017; Celik, Sanberk and Deveci, 2017; Tepeli-Temiz, 2017; Shi, Wang, Bian and Wang, 2015; Rani and Midha, 2014; Achour, and Nor 2014; UlkerTumlu and Recepoglu, 2013; Liu, Wang and Li, 2012; Limonero, Tomas-Sabado, FernandezCastro, Gomez-Romero and Ardilla-Herrero, 2012). In a study conducted by Kong, Wang, Huand Liu, (2015), it is emphasized that life satisfaction and psychological resilience are related, and there are neural substrates that link psychological resilience and life satisfaction. 


\section{Limitations}

This research contains some limitations. Humor is a concept with different types (Kim, 2019; Evans and Steptoe-Warren, 2018). In this research, only general sense of humor was studied. This situation is considered to be one of the limitations of the research. Psychological resilience is a concept influenced by culture (Graber, Pichon and Carabine, 2015). The study group of this research consists of teacher candidates studying in a city in Central Anatolia. In this respect, it can be thought that the study group is one of the factors that cause the limitation of the research.

\section{Recommendations}

The study group of this research consists of teacher candidates who continue their education at a university in Central Anatolia Region. It is thought that the repetition of the research with different age groups and cultures will increase the generalizability. In this study, females' psychological resilience was found higher than that of males. Learning about the roles and duties of genders is important for psychological resilience (Smyth and Sweetman, 2015). In future researches, the effect of not only gender but also gender roles on psychological resilience can be investigated.

In this study, a significant relationship was found between sense of humor and psychological resilience. Evidence for the effectiveness of humor-based positive psychology interventions is growing (Wellenzohn, Proyer and Ruch, 2018). For this reason, individual and group counseling service based on humor can be provided to increase the psychological resilience of teacher candidates.

\section{References}

Achour, M. \&Nor, M. R. M. (2014). The effects of social support and resilience on life satisfaction of secondary school students. Journal of academic and applied studies, 4(1), 12-20.

Ak, A. H. (2019). Universite ogrencilerinin psikolojik dayanikliliginin kisilik ozellikleri ve farkli baglanma turleri ile iliskisinin incelenmesi. (Yayimlanmamis yuksek lisans tezi). Hasan Kalyoncu Universitesi Sosyal Bilimler Enstitusu, Gaziantep.

Akdogan, B. \& Yalcin, S. (2018). Lise Ogrencilerinin Psikolojik Dayaniklilikve Catisma Cozme Davranislarinin Oznellyi Oluslarini Yordamasi. Mehmet Akif Ersoy Universitesi Egitim Fakultesi Dergisi, (46), 174-197 . DOI: 10.21764/maeuefd.370587

Altundag, Y. \& Bulut, S. (2014). Prediction of resilience of adolescents whose parents are divorced. Psychology, 2014.10.4236/psych.2014.510134

Arslan, G. \& Balkis, M. (2016). Ergenlerde Duygusal Istismar, Problem Davranislar, Ozyeterlik ve Psikolojik Saglamlik Arasindaki Iliski. Sakarya University Journal of Education, 6 (1), 8-22. https://doi.org/10.19126/suje.35977

Aslan, S.H., Alparslan, Z.N., Evlice, Y.E., Aslan, R.O. \& Cenkseven, F. (1999). Cok Boyutlu Mizah Duygusu Olcegi: Faktor Yapisi, Guvenirlik ve Gecerlik Calismasi. Psikiyatri Psikoloji Psikofarmakoloji (3P) Dergisi, 7(1), 33-39. 
Aydin, I., Oncu, E., Akbulut, V. \& Kucuk Kilic, S. (2019). Ogretmen Adaylarinda Bos Zaman Sikilma Algisi ve Psikolojik Saglamlik iliskisi. Beden Egitimi ve Spor Bilimleri Dergisi, 21 (1), 39-53 . Erisim: https://dergipark.org.tr/tr/pub/ataunibesyo/issue/43861/518563

Aydin, M. \& Egemberdiyeva, A. (2018). Universite Ogrencilerinin Psikolojik Saglamlik Duzeylerinin Incelenmesi. Turkiye Egitim Dergisi3 (1), 37-53. https://dergipark.org.tr/tr/download/article-file/496083

Aydogdu, T. (2013). Baglanma stilleri, basa cikma stratejileri ile psikolojik dayaniklilik arasindaki iliskinin incelenmesi. (Yayinlanmamis yuksek lisanstezi). Gazi Universitesi Egitim Bilimleri Enstitusu, Ankara.

Bailey, T. C., Eng, W., Frisch, M. B.\& Snyder, C. R. (2007). Hope and optimism as related to life satisfaction. The Journal of Positive Psychology, 2(3), 168175.10.1080/17439760701409546

Bakan, I., Guler, B. (2017). Duygusal Zekanin, Yasam Doyumu ve Akademik Basariya Etkilerive Demografik Ozellikler Baglaminda Algi Farkliliklari. KMU Sosyal ve Ekonomik Arastirmalar Dergisi, 19 (33), 1-11. Erisim: http://hdl.handle.net/11492/1296

Basim, H.N.\& Cetin, F. (2011). Yetiskinler icin Psikolojik Dayaniklilik Olcegi'nin Guvenirlilik ve Gecerlilik Calismasi. Turk Psikiyatri Dergisi, 22(2), 104-114. Erisim: http://www.turkpsikiyatri.com/PDF/C22S2/104-114.pdf

Bektas, M. \& Ozben, S. (2016). Evli Bireylerin Psikolojik Dayaniklilik Duzeylerinin Bazi SosyoDemografik Degiskenler Acisindan Incelenmesi. Celal Bayar Universitesi Sosyal Bilimler Dergisi 14 (1), o-o. DOI: 10.18026/cbusos.16929

Bhattacharyya, P., Jena, L. K.\& Pradhan, S. (2019). Resilience as a Mediator Between Workplace Humour and Well-being at Work: An Enquiry on the Healthcare Professionals. Journal of Health Management, 21(1), 160-176.10.1177/0972063418821815

Bozgeyikli, H.\&Sat, A. (2014). Ogretmenlerde Psikolojik Dayaniklilik Ve Orgutsel Vatandaslik Davranislarinin Bazi Degiskenler Acisindan Incelenmesi: Ozel Okul Ornegi. Hak-ls Uluslararasi Emekve Toplum Dergisi 3 (5), https://dergipark.org.tr/en/download/articlefile/84797

Buyuksahin Cevik, G., Dogan, I. \& Yildiz, M.A. (2016). Pedagojik Formasyon Egitimi Alan Ogrencilerin Yilmazlik ve Tukenmisliklerinin Incelenmesi. Mersin Universitesi Egitim Fakultesi Dergisi, 12(3), 971-984. https://doi.org/10.17860/mersinefd.282395

Cann, A., \& Collette, C. (2014). Sense of humor, stable affect, and psychological wellbeing. Europe's Journal of Psychology, 10(3), 464-479. https://doi.org/10.5964/ejop.v10i3.746

Celik, M., Sanberk, I.\&Deveci, F. (2017). Ogretmen Adaylarinin Yasam Doyumlarinin Yordayicisi Olarak Psikolojik Dayaniklilik ve Umutsuzluk. Ilkogretim Online, 16(2), 654-662, 2017. doi: 10.17051/ilkonline.2017.304725

Cetinkaya, A.\&Sarici-Bulut, S. (2019). Lise Ogrencilerinde Kendini Toparlama Gucu Duzeylerive Oznel lyi olusu Artirma Stratejilerinin Incelenmesi. Turk Psikolojik Danisma ve Rehberlik Dergisi, 9 (55), 1053-1084. https://dergipark.org.tr/en/pub/tpdrd/issue/51223/666919

Choi, K. W., Stein, M. B., Dunn, E. C., Koenen, K. C. \&Smoller, J. W. (2019). Genomics and psychological resilience: a research agenda. Molecular psychiatry, 1-9.

Ciftci-Aridag, N. \& Unsal-Seydoogullari, S. (2019). Lise Ogrencilerinin Yasam Doyumu ve Yilmazlik Duzeylerinin Anne Baba Tutumlariyla Iliskisi Acisindan Incelenmesi. Hacettepe Universitesi Egitim Fakultesi Dergisi, 34(4), 1037-1060. doi: 10.16986/HUJE.2018038527

Cohn, M. A., Fredrickson, B. L., Brown, S. L., Mikels, J. A. \& Conway, A. M. (2009). Happiness Unpacked: Positive Emotions Increase Life Satisfaction By Building Resilience. Emotion, 9(3), 361-368. doi:10.1037/a0015952 
Diener, E., Emmons, R. A., Larsen, R. J. \& Griffin, S. (1985). The satisfaction with life scale. Journal of Personality Assessment, 49 (1), 71-75.

Dogru, G. (2019). Travma yasantisi olan bireylerde travma sonrasi bilislerin, travmaya bagli suclulugun ve control odaginin obsesif-kompulsif bozukluk belirtileri uzerindeki yordayici etkisi. (Yayimlanmamis yuksek lisans tezi). Hacettepe Universitesi Sosyal Bilimler Enstitusu, Ankara.

Durmus, M. \& Okanli, A. (2018). Universite ogrencilerinin problem cozme becerileri ile psikolojik dayaniklilik duzeylerinin degerlendirilmesine yonelik bir arastirma. Yasam Becerileri Psikoloji Dergisi, 2(4), 177-189. https://doi.org/10.31461/ybpd.452094

Erdinc, I. (2018). Evli ciftlerde, evlilik uyumu, cinsel yasam doyumu ve yasam doyumu arasinda $k i$ iliskinin incelenmesi. (Yayimlanmamis yuksek lisans tezi). Istanbul Gelisim Universitesi Sosyal Bilimler Enstitusu, Istanbul.

Evans, T. R.\& Steptoe-Warren, G. (2018). Humor style clusters: Exploring managerial humor. International journal of business communication, 55(4), 443-454. https://doi.org/10.1016/j.lindif.2017.04.008

Fletcher, D.\& Sarkar, M. (2013). Psychological resilience: A review and critique of definitions, concepts, and theory. European psychologist, 18(1), 12. 10.1027/1016-9040/a000124

Friborg, O.,Hjemdal, O., Rosenvinge, J. H. \& Martinussen, M. (2003). A new rating scale for adult resilience: what are the central protective resources behind healthy adjustment? International journal of methods in psychiatric research, 12(2), 65-76. 10.1002/mpr.143

Gaur, A. S.\& Gaur, S. S. (2006). Statistical methods for practice and research: A guide to data analysis using SPSS. Sage.

George, D. \& VeMallery, P. (2019). IBM SPSS Statistics 25 Step By Step (15. B.).

Graber, R., Pichon, F. \& Carabine, E. (2015). Psychological resilience. London: Overseas Development Institute.

Grotberg, E. (1995). A Guide to Promoting Resilience in Children: Strengthening The Human Spirit. Early Childhood Development: Practice and Reflections, 8. Erisim: http://www.bibalex.org/Search4Dev/files/283337/115519.pdf

Gungormus, K., Okanli A. \& Kocabeyoglu T. (2015). Hemsirelik Ogrencilerinin Psikolojik Dayanikliliklari ve Etkileyen Faktorler. Psikiyatri Hemsireligi Dergisi, 6 (1), 9-14 Erisim: http://www.journalagent.com/phd/pdfs/PHD-80299-RESEARCH_ARTICLEGUNGORMUS.pdf

Henderson, N.\& Milstein, M. M. (1996). Resiliency In Schools: Making It Happen For Students And Educators. Thousand Oaks, California: Corwin Press. Erisim:

https://books.google.com.tr/books?id=F1y6Q-

NTgpEC\&pg=PA12\&hl=tr\&source=gbs_selected_pages\&cad $=3 \# v=$ onepage $\& q \& f=$ false

Ho, R. (2016). Handbook of univariate and multivariate data analysis with IBM SPSS. CRC press.

Huang, S., Han, M., Sun, L., Zhang, H. \& Li, H. J. (2019). Family socioeconomic status and emotional adaptation among rural-to-urban migrant adolescents in China: The moderating roles of adolescent's resilience and parental positive emotion. International Journal of Psychology, 54(5), 573-581. doi: 10.1002/ijop.12499.

Hughes, L. W. (2008). A correlational study of the relationship between sense of humor and positive psychological capacities. Economics \& Business Journal: Inquiries \& Perspectives.

Isik, S. (2016). Turkiye' de Kendini Toparlama Gucu Konusunda Yapilmis Arastirmalarin Incelenmesi. Turk Psikolojik Danisma ve Rehberlik Dergisi, 6 (45), 65-76. https://dergipark.org.tr/en/pub/tpdrd/issue/42745/515929

Judd, M. W. (2016). The Moderating Effects of Positive and Negative Automatic Thoughts on the Relationship Between Positive Emotions and Resilience. Electronic Theses and Dissertations, 1363. https://digitalcommons.georgiasouthern.edu/etd/1363/ 
Kaner, S., Bayrakli, H. \& Guzeller, C.O. (2011). Anne-Babalarin Yilmazlik Algilarinin Bazi Degiskenler Acisindan İncelenmesi. Ankara Universitesi Egitim Bilimleri Fakultesi Ozel Egitim Dergisi, 12 (2). 63-78.

Kannan, K. S. \& Manoj, K. (2015). Outlier detection in multivariate data. Applied Mathematical Sciences, 47, 2317-2324.

Karairmak, O. \& Sivis-Cetinkaya, R. (2011). Benlik Saygisinin ve Denetim Odaginin Psikolojik Saglamlik Uzerine Etkisi: Duygularin Araci Rolu. Turk Psikolojik Danisma ve Rehberlik Dergisi, 4 (35), 30-43. http://www.turkpdrdergisi.com/index.php/pdr/article/view/177/107

Karlyk-Cwik, A. (2016). Humor Styles In Socially Maladjusted Girls And Boys: A Resilience Perspective. Cbu International Conference On Innovations In Science And Education, 4, 464-470. DOI: https://doi.org/10.12955/cbup.v4.799

Karmalkar, S. J. \& Vaidya, A. (2018). Resilience of rural-to-urban migrant adolescents: The role of gender and socio-economic status. Indian Journal of Health \& Wellbeing, 9(1).

Kaur, J. (2011). Influence of gender and school climate on psychological hardiness among Indian adolescents. In International Conference on Social Science and Humanity (Vol. 5, pp. 319-323).

Kilic, D. S. \& Alver, B. (2017). Universite Ogrencilerinin Yalnizlik Duzeyleri Ve Psikolojik Dayanikliliklari Arasindaki Iliskilerin Bazi Degiskenlere Gore Incelenmesi. International Journal of Education Technology and Scientific Researches, 2(3), 116-147.

Kim, J. (2019). Analysis on the Correlation of Humor Style Types Shown in. Journal of Digital Convergence, 17(11), 157-162.

Kindiroglu, Z. \& Yasar-Ekici, F. (2019). Ebeveynlerin Psikolojik lyi Olus ve Psikolojik Dayaniklilik Duzeyleri ile Cocuklarin Sosyal Yetkinlik ve Davranislari Arasindaki İliski. Adiyaman $\begin{array}{llll}\text { Universitesi Egitim Bilimleri 138-157. } & \text { 9(1), }\end{array}$ https://doi.org/10.17984/adyuebd.458224

Koc-Yildirim, P., Yildirim, E., Otrar, M. \& Sirin, A. (2015). Ergenlerde Psikolojik Dayaniklilik ile Benlik Kurgusu Arasindaki Iliskinin Incelenmesi. Marmara Universitesi Ataturk Egitim Fakultesi Egitim Bilimleri Dergisi, 42, 277-297. DOI: 10.15285/ebd.58203

Koker, S. (1991). Normal ve sorunlu ergenlerin yasam doyumu duzeylerinin karsilastirilmasi. (Yayinlanmamis yuksek lisanstezi). Ankara Universitesi Sosyal Bilimler Enstitusu, Ankara.

Kong, F., Wang, X., Hu, S. \& Liu, J. (2015). Neural correlates of psychological resilience and their relation to life satisfaction in a sample of healthy young adults. Neuroimage, 123, 165-172. https://doi.org/10.1016/j.neuroimage.2015.08.020

Levine, J. (2017). Approaches to Humor Appreciation, in L. Jacob (Ed.). Motivation in Humor. New York: Routledge.

Limonero, J. T., Tomas-Sabado, J., Fernandez-Castro, J., Gomez-Romero, M. J. \& ArdillaHerrero, A. (2012). Estrategias de afrontamiento resilientes y regulación emocional: predictores de satisfaccion con la vida. Behavioral Psychology/ Psicologia Conductual, 20(1).

Limura, S. \&Taku, K. (2018). Gender differences in relationship between resilience and big five personality traits in Japanese adolescents. Psychological reports, 121(5), 920-931. 10.1177/0033294117741654

Liu, Y., Wang, Z. \& Lu, W. (2013). Resilience and affect balance as mediators between trait emotional intelligence and life satisfaction. Personality and Individual differences, 54(7), 850-855. https://doi.org/10.1016/j.paid.2012.12.010

Liu, Y., Wang, Z. H. \& Li, Z. G. (2012). Affective mediators of the influence of neuroticism and resilience on life satisfaction. Personality and Individual Differences, 52(7), 833-838. 10.1016/j.paid.2012.12.010 
Maiolino, N. B. \& Kuiper, N. A. (2014). Integrating humor and positive psychology approaches to psychological well-being. Europe's Journal of Psychology, 10(3), 557-570. https://doi.org/10.5964/ejop.v10i3.753

Malkoc, A., Yalcin, I. (2015). Universite Ogrencilerinde Psikolojik Dayaniklilik, Sosyal Destek, Basa Cikma ve lyi-Olus Arasindaki Iliskiler. Turk Psikolojik Danisma ve Rehberlik Dergisi, 5 (43), 35-43. http://turkpdrdergisi.com/index.php/pdr/article/download/4/5

Martin, R. A. (2006). The psychology of humor. Burlington, MA: Elsevier.

McKay, L. \& Barton, G. (2018). Exploring how arts-based reflection can support teachers' resilience and well-being. Teaching and Teacher Education, 75, 356-365. https://doi.org/10.1016/j.tate.2018.07.012

Newsome, J., Vaske, J.C., Gehring, K.S., Boisvert, D.L. (2015). Sex Differences in Sources of Resilience and Vulnerability to Risk for Delinquency. Journal of Youth and Adolescence, 45(4), 730-745. doi:10.1007/s10964-015-0381-2

Onat, G. (2010). Demokratik ve otoriter olarak algilanan ana-baba tutumlarinin lise birinci sinif ogrencilerinin yilmazlik duzeyine etkilerinin arastirilmasi. (Yayimlanmamis yuksek lisans tezi). Maltepe Universitesi, Sosyal Bilimler Enstitusu, Istanbul.

Papousek, I., Lackner, H.K., Weber, B., Perchtold, C.M., Fink, A.\& Weiss, E.M. (2019). Poor Control of Interference From Negative Content Hampers The Effectiveness of Humour As a Source of Positive Emotional Experiences. Scientific Reports 9, 8023. https://doi.org/10.1038/s41598-019-44550-3

Proctor, C. L., Linley, P. A. \& Maltby, J. (2009). Youth life satisfaction: A review of the literature. Journal of happiness studies, 10(5), 583-630. DOI 10.1007/s10902-008-9110-9

Ramos-Diaz, E., Rodriguez-Fernandez, A., Axpe, I. \& Ferrara, M. (2019). Perceived Emotional Intelligence and Life Satisfaction Among Adolescent Students: The Mediating Role of Resilience. Journal of Happiness Studies, 20(8), 2489-2506. https://doi.org/10.1007/s10902-018-0058-0

Rani, R. \& Midha, P. (2014). Does resilience enhance life satisfaction among teenagers. Journal of Humanities and Social Science, 19(6), 16-19. 10.9790/0837-19671619

Sabouripour, F. \& Roslan, S. B. (2015). Resilience, optimism and social support among $\begin{array}{lllll}\text { international students. Asian Social } & \text { Science, 11(15), } & 159 .\end{array}$ http://dx.doi.org/10.5539/ass.v11n15p159

Sahin-Baltaci, H. \&Karatas, Z. (2015). Perceived Social Support, Depression and Life Satisfaction as the Predictor of the Resilience of Secondary School Students: The Case of Burdur. Eurasian Journal of Educational Research, 60, 111-130. 10.14689/ejer.2015.60.7

Sarikaya, A. (2015). 14-18 yas arasi ergenlerin benlik saygisi ve psikolojik dayaniklilik duzeyleri arasindaki iliski. (Yayimlanmamis yuksek lisanstezi). Istanbul BilimUniversitesi Sosyal Bilimler Enstitusu, Istanbul.

Sezgin, F. (2012). Ilkogretim Okulu Ogretmenlerinin Psikolojik Dayaniklilik Duzeylerinin Incelenmesi. Kastamonu EgitimDergisi 2 (20), 489-502. https://dergipark.org.tr/en/download/article-file/806957

Shaughnessy, J. J., Zechmeister, E. B. \&Zechmeister, J. S. (2012). Research methods in psychology. McGraw-Hill.

Sheard, M. (2009). Hardiness commitment, gender, and age differentiate university academic performance. British Journal of Educational Psychology, 79(1), 189-204. DOI:10.1348/000709908X304406

Shi, M., Wang, X., Bian, Y. \& Wang, L. (2015). The mediating role of resilience in the relationship between stress and life satisfaction among Chinese medical students: a cross-sectional study. BMC medical education, 15(1), 16. DOI 10.1186/s12909-015-0297-2 
Shin, J., Taylor, M. S. \& Seo, M. G. (2012). Resources for change: The relationships of organizational inducements and psychological resilience to employees' attitudes and behaviors toward organizational change. Academy of Management journal, 55(3), 727748. http://dx.doi.org/10.5465/amj.2010.0325

Smith, R. E. \& Ascough, J. C. (2016). Promoting emotional resilience: Cognitive-affective stress management training. Guilford Publications.

Smyth, I. \& Sweetman, C. (2015). Introduction: Gender and resilience. Gender \& Development, 23(3), 405-414.https://doi.org/10.1080/13552074.2015.1113769

Sousa, L.\& Lyubomirsky, S. (2001). Life satisfaction. In J. Worell (Ed.), Encylopedia of women and gender: Sex similarities and differences and the impact of society on gender (Vol. 2, pp. 667-676). San Diego, CA, USA: Academic Press.

Tasgin, O., Bozgeyikli, H. \& Bogazliyan, E.E. (2017). Universiteli Genclerin Issizlik Kaygilari Ile Psikolojik Dayanikliliklari Arasindaki Iliski. Hak-Is Uluslararasi Emek Ve Toplum Dergisi 6 (15).

Tepeli-Temiz, Z. T. (2017). Universite ogrencilerinin baglanma stilleri ile yasam doyumu, psikolojik dayaniklilik ve aleksitimik ozellikleri arasindaki iliskide benlik saygisinin rolu. (Yayimlanmamis yuksek lisans tezi). Fatih Sultan Mehmet Vakif Universitesi Sosyal Bilimler Enstitusu, Istanbul.

Thorson, J. A. \& Powell, F. C. (1993). Development and validation of a multidimensional sense of humor scale. Journal of clinical psychology, 49(1), 13-23. https://doi.org/10.1002/10974679(199301)49:1<13::AID-JCLP2270490103>3.0.CO;2-S

Tras, Z., Arslan, C. \& Mentis-Tas, A. (2011). Ogretmen Adaylarinda Mizah Tarzlari, Problem Cozme ve Benlik Saygisinin Incelenmesi. Uluslararasi Insan Bilimleri Dergisi, 8, 2. Erisim: http://www.insanbilimleri.com

Tras, Z., Oztemel, K. \& Kagnici, E. (2019). A Review on University Students' Resilience and Levels of Social Exclusion and Forgiveness. International Education Studies, 12(10). 10.5539/ies.v12n10p50

Ulker-Tumlu, G. \& Recepoglu, E. (2013). Universite Akademik Personelinin Psikolojik Dayaniklilik ve Yasam Doyumu Arasindaki Iliski. Yuksekogretim ve Bilim Dergisi, 3 (3), 205-213. DOI: 10.5961/jhes.2013.078.

Wellenzohn, S., Proyer, R. T. \& Ruch, W. (2018). Who benefits from humor-based positive psychology interventions? The moderating effects of personality traits and sense of humor. Frontiers in psychology, 9, 821.https://doi.org/10.3389/fpsyg.2018.00821

Wijewardena, N., Hartel, C. E. \& Samaratunge, R. (2010). A laugh a day is sure to keep the blues away: Managers' use of humor and the construction and destruction of employees' resilience. In Emotions and organizational dynamism. Emerald Group Publishing Limited. 10.1108/S1746-9791(2010)0000006014

Yakici, E. \& Tras, Z. (2018). Life satisfaction and loneliness as predictive variables in psychological resilience levels of emerging adults. Research on Education and Psychology, 2(2), 176-184.

Yaprak, P., Guclu, M. \& Ayyildiz Durhan, T. (2018). The Happiness, Hardiness, and Humor Styles of Students with a Bachelor's Degree in Sport Sciences. Behavioral Sciences, 8(9), 82. $10.3390 / \mathrm{bs} 8090082$

Yavuz, B. (2019). Ogretmen adaylarinda psikolojik dayaniklilik ve bilincli farkindalik arasindaki iliski: Manevi iyi olusun rolu. (Yayimlanmamis yuksek lisans tezi). İstanbul Sabahattin Zaim Universitesi, Sosyal Bilimler Enstitusu, İstanbul.

Zhang, J., Yu, N. X., Zhang, J. \& Zhou, M. (2017). Sense of community and life satisfaction in Chinese older adults: Moderating roles of personal and partner resilience. Journal of Community Psychology, 45(5), 577-586.https://doi.org/10.1002/jcop.21878 
Zheng, W., Huang, Y. \& Fu, Y. (2020). Mediating effects of psychological resilience on life satisfaction among older adults: A cross-sectional study in China. Health \& Social Care in the Community. https://doi.org/10.1111/hsc

\section{Biografical Notes:}

Zeliha Traş is a professor of psychological counseling and guidance at the Faculty of Education, Necmettin Erbakan University, Konya, Turkey. She holds a PhD in psychological counseling and guidance from Selcuk University. Her research interests include psychological counseling and guidance, internet addiction, social support, resilience, social appearance.

Büşra Kabakçı is an master student of psychological counseling and guidance at the Faculty of Education, Necmettin Erbakan University, Konya, Turkey. She holds a degree in psychological counseling and guidance from Necmettin Erbakan University. Her research interests include psychological counseling and guidance, internet addiction, resilience, humor .

Umay Bilge Baltacı is an doctorate student of psychological counseling and guidance at the Faculty of Education, Necmettin Erbakan University, Konya, Turkey. She holds a PhD in psychological counseling and guidance from Necmettin Erbakan University. Her research interests include psychological counseling and guidance, internet addiction, suicide cognitions, social appearance anxiety, coping with stress. 